\title{
Research on the Current Development Conditions of Non-governmental Youth Organizations in Colleges and Universities
}

\author{
Fengqiu Jin \\ Harbin Institute of Technology \\ Harbin, China
}

\author{
Zongyi Yang \\ Harbin Institute of Technology \\ Harbin, China
}

\author{
Ying Yuan \\ Harbin Institute of Technology \\ Harbin, China
}

\begin{abstract}
As the existence of self-media, the society develops more rapidly and students are more ideological and more diverse. Non-governmental youth organizations are booming largely which greatly meets the growing requirements of the students. At the same time, because its spontaneity and openness, it also brings side effects on the college students management and ideological education. The author researched the current developing conditions of non-governmental youth organizations in this paper, aims at putting up with some effective measures to guide the organization to develop healthily and play a positive role.
\end{abstract}

Keywords-colleges and universities; non-governmental youth organization; ideological education; management measures

\section{INTRODUCTION}

Non-governmental youth organizations in colleges and universities, refer to those don't register in the local civil affairs departments, without legal person status, or don't record in relevant departments in the school, form by college students spontaneously and operate by students themselves but act frequently in colleges and universities ${ }^{[1]}$. Studies have defined characteristics of non-governmental youth organizations as follows: the specificity of the main body, openness of organization, deliberation of learning, standard spontaneity and flexibility of activities ${ }^{[2]}$. Comprehensively speaking, non-governmental youth organizations have the characteristics of young students smell and networking tendency in addition to the characteristics of the general youth organizations. They have positive and negative effects on the campus ecological culture. The positive effect ${ }^{[3]}$ is that they can satisfy young students growing demands and help students grow better, well, the negative effect is this kind organizations are lack of certain management and restraint, which will lead to existence of labile factors. Therefore, How to correctly understand and guide the non-governmental youth organizations and make them develop in a direction conducive to student's growth has important realistic meaning in cultivating qualified builders and reliable successors for the

Corresponding author: Jin Fengqiu socialist cause and maintaining the harmony and stability in colleges and universities ${ }^{[4]}$. To understand the causes, development status and social influence of non-governmental youth and make them develop healthily and orderly, the author takes Harbin Institute of Technology as an example and conducts a study of non-governmental youth organizations.

\section{BASIC CONDITIONS OF THE RESEARCH}

To understand the developing conditions fully and put forward effective management measures, the author makes a questionnaire on the problem in Harbin Institute of Technology. The questionnaire was designed on the basis of pertinent literatures and actual conditions of this project. It was made up of 30 questions and mainly asked the causes, scale, member structure, operation patterns, activity frequency and development directions. The total number of giving questionnaires is 600, the recovery is 586. Distributed object are undergraduates and master degree candidates majoring in science, engineering, liberal arts in Harbin Institute of Technology. The recycling effective questionnaires are 583 so questionnaire effective rate is $99.5 \%$. Questionnaire basically covers the entire school students and the male and female ratio is $7: 1$, roughly in accordance with the actual situation so the investigation has wide representativeness. On the basis of questionnaire survey, the author also holds seminars and individual interview and communicates with leaders and members of some non-governmental youth organizations to add the content of the questionnaire.

\section{THE RISING REASONS OF NON-GOVERNMENTAL YOUTH ORGANIZATIONS IN COLLEGE AND UNIVERSITIES}

Taking the case study of Harbin Institute of Technology, the communist youth league gives development services and thought leading for its members in the entire school, vigorously supports the development of all kinds of student associations registered in the school and actively understands and satisfies the demand of the young. However, nongovernmental youth organizations still develop boomingly. 
Combining with the campus and social factors, questionnaire and interviews and summarizing the rising reasons of the nongovernmental youth organizations, there are basically the following three points.

\section{A. Changes of Campus Environment Provide the Base for Non-governmental Youth Organizations}

Comparing to the environment in high school, that in colleges and universities is open. To a large extent, students can arrange their study and life according to themselves. At the same time, teaching patterns and credits system in colleges and universities weaken class and cohesion gradually. Students lost sense of belonging weakens formal organizations concept and alienates the feeling. All of these outside conditions provide bases for non-governmental youth organizations.

\section{B. Young Individuals Are the Internal Agent for Non- governmental Youth Organizations}

Psychological needs are the theory foundation and the root cause of rapid development of non-governmental youth organizations. As college students away from home feel lonely without warmth of class so it is easy to form the organizations similar to "townsmen natives association" in search of belonging senses. Survey shows that $30.8 \%$ interviewees' motivation for the young to join non-governmental youth organizations is finding the sense of belonging. Meanwhile, the respondents choose "expanding social relationship" are up to $42.1 \%$. In addition, another $12.6 \%$ interviewees choose "realizing ability and value". These young students can't apply themselves in formal organizations so they choose to join nongovernmental youth organizations. Therefore, expanding social relationship, finding the sense of belonging and realizing ability and value are the main reasons for college students to join non-governmental youth organizations.

\section{The Popularization of Internet Accelerates the Rapid Development of Non-governmental Youth Organizations}

With the popularization of internet and the coming of new media age, formal organizations like student union, associations and classes can't cover all the students. Nongovernmental youth organizations based on internet take the opportunity and develop fast. Surveys show that, In terms of composition and communication of non-governmental youth organizations, there are up to $73 \%$ such organizations based on the internet. The most typical organizations are townsmen natives associations and interest clubs and kinds of QQ Groups, which communicate on the internet. In addition, there are still 7.8\% non-governmental youth organizations based on the internet, the members don't know each other in reality and only communicate and act on the internet. For example in the individual interview, an interviewee mentioned an E-sports club he joined, and most members of it are college students. They are interested in E-sports skills, E-sports events and Star players, so they communicate every day. They also talk about things in life. Even they haven't seen each other ever, they trust each other.

\section{TYPES OF NON-GOVERNMENTAL YOUTH ORGANIZATIONS IN COLLEGES AND UNIVERSITIES}

The non-governmental youth organizations result from environmental factors and individual needs. College students come from all over the country, and their family backgrounds, personality characteristics and hobbies are different from each other. So the non-governmental youth organizations catering to the needs of the young are various. These organizations are formed according to karmic connection, interest margin and geographical relationship and involve entertainment, making friends, sports, e-sports, travelling, environment protection and public welfare. According to the research data, the author analyzes the types of non-governmental youth organizations as follows:

Non-governmental youth organizations of interest margin are formed on the basic of common interest and to satisfy the spiritual life of members. They include interest organizations connected by recreational and sports activities, network, star and teams and researching organizations connected by certain majors and scholastic directions. Interest organizations contain fan clubs and health clubs. Researching organizations contain English corners, reading parties and Beijing Opera enthusiasts clubs. Common interests are the base for non-governmental youth organizations of interest margin to form and develop so such organizations are the largest, most common and wide in colleges and universities. Survey shows that non-governmental youth organizations of interest margin occupies.

Non-governmental youth organizations of geographical relationship refer to those formed according to geographical reasons such as students born in same place and have common learning experiences. Typical geographical organizations are townsmen natives associations and alumni associations. Such as Sichuan natives association and Changsha no.1 middle school alumni association. Non-governmental youth organizations of geographical relationship can give belonging sense to college students far away from home better. These kind organizations count $29.47 \%$.

Non-governmental youth organizations of karmic connection, refer to those take certain career as the goal in colleges and universities. Different from non-governmental youth organizations of interest margin, they have clear developing goal such as exam comrades groups, employment alliance, supporting education groups and environmental protection groups. They count $24.24 \%$ according to the survey.

\section{CURRENT DEVELOPING CONDITIONS OF NON-} GOVERNMENTAL YOUTH ORGANIZATIONS IN COLLEGES AND UNIVERSITIES

\section{A. Scale of Youth Non-governmental Organizations in Colleges and Universities}

Survey shows that non-governmental youth organizations are very popular because of their rich types and satisfactions to the demands of the young. $79.7 \%$ students interviewed join non-governmental youth organizations and $67.7 \%$ among them join 2 organizations. Data shows that scales of the major nongovernmental youth organizations in colleges and universities are small, non-governmental youth organizations of less than 
50 people account for $62.3 \%$, 50 to 100 people account for $20.1 \%$, more than 100 people account for $17.6 \%$.

\section{B. Developing Period of Non-governmental Youth Organizations}

Survey shows that organizations the interviewees joined have developed for a short time. There are $71.4 \%$ organizations has developed for less than three years and $43.2 \%$ among these organizations have developed for less than one year. Just $6.6 \%$ organizations have developed for more than five years. This reflects that the life term of nongovernmental youth organizations is shorter than formal organizations. Therefore, the further development of nongovernmental youth organizations needs the support and guidance of related department.

\section{Operation and Management of Non-governmental Youth Organizations}

Internet is the dominant operation methods and access because of its openness, freedom and low cost. Planning, discussion, release, reflection and member management are done on the internet. The vast majority of organizations have their own QQ groups or Wechat groups so they can communicate and discuss activities directly and effectively. There are $97.8 \%$ organizations mainly connected by internet in the survey.

In terms of management, activities held by nongovernmental youth organizations are initiative. They are free because they don't appeal to examine and approve. While in terms of activity decision, the survey shows that $76.1 \%$ of the organizations make decisions by common discussion. Meanwhile, they don't restrain members to attend activities. Comparing to formal students organizations, nongovernmental youth organizations are freer and looser.

\section{Activities Held by Non-governmental Youth Organizations}

From the point of activity frequency and duration, nongovernmental youth organizations don't hold activities frequently, but every activity they held lasts long. According to the survey, non-governmental youth organizations hold once in a quarter on average accounts for $61.6 \%$, those more than once account for $21.3 \%$. Among them $80.1 \%$ activity duration is more than two hours and $13 \%$ more than five hours.

From the perspective of the participation satisfaction degree, the members of non-governmental youth organizations are higher. More than $84.1 \%$ of the members are satisfied with activities according to the survey and only $6 \%$ of the members are not satisfied. So most of the members are positive to participate in the activities, they account for $76.9 \%$. At the same time, the organization members generally reflect that participating in the organization brings positive influence including expanding social relationship, finding the sense of belonging and realizing personal value. Above results of the survey shows that activities held by non-governmental youth organizations are qualified even though they are not frequent and they satisfy members. They form a distinctive contrast with the official student organization activities with more frequency and less appeal.

\section{MEASURE FOR DEVELOPMENT OF NON- GOVERNMENTAL YOUTH ORGANIZATIONS}

\section{A. Correctly Understanding the Development of Non- governmental Youth Organizations in Colleges and Universities}

Educators in colleges and universities should fully realize the objectiveness of non-governmental youth organizations. The rise and development of non-governmental youth organizations are the inevitable in a certain social background. They are the result of economic and social development and civilization progress and also the inevitable requirements of youth development and youth culture diversification. Nongovernmental youth organizations have both positive and negative effects on campus and society, so educators in colleges and universities should enhance advantages and avoid disadvantages, guide non-governmental youth organizations to turn to formal organizations and keep them positive and active.

\section{B. Strengthening Researches on Non-governmental Youth Organizations in Colleges and Universities}

Non-governmental youth organizations in colleges and universities are results of society, alumni environment and youth individual demands. Organizations with different students or in different stages have different characteristics. Therefore, educators should research non-governmental youth organizations clearly to collect materials and know the need and developing conditions of the organizations. They can manage students in colleges and universities with a purpose and guide organizations to develop well. Meanwhile, they can give advice and reference to members of formal organizations to serve students better.

\section{Classified Guidance: Giving Classification Guidance to Promote Non-governmental Youth Organizations Operate Regularly}

Educators should give classified guidance to students of non-governmental youth organizations on the basic conditions.

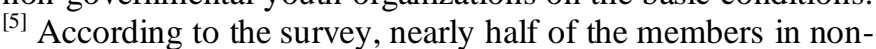
governmental youth organizations support to turn informal organizations to formal organizations under suitable conditions. For such organizations, the colleges and universities should give special support and guidance, for example, they can provide activities places and funds, to lead the transition to formal organizations. For those don't agree to turn, they should supervise and guide well to ensure correct political orientation and positive contents of the organizations.

\section{Guiding the Leaders of Non-governmental Youth Organizations Well}

Non-governmental youth organizations are operated by one or more core people from existence. They have strong organizing ability and rallying power and connect members by their personality charm and emotion. Core people play a leader role in irregular and non-systemic organizations. So knowing the core people well, educating and guiding them according to conditions of different activities and keeping regular contact with them are conducive to catching information of non- 
governmental youth organizations and guiding organizations directly.

\section{E. Improving Service Quality and Attraction of Formal Organizations}

The development of non-governmental youth organizations challenges formal student organizations and brings new demands on them. To adapt change of times, the trend of social development and change of students groups, formal student organizations must change thinking ways, research youth demands and ideological conditions and innovate work system to serve students better.

\section{REFERENCES}

[1] Du Lanxiao. An analysis on the Problems of Non-governmental Youth Organizations[J]. China Higher Education Research. May, 2009. Page74-76.

[2] Gao Yongliang. A Research on the development of Non-governmental Youth Organizations[J]. China Youth Study. May, 2010. Page44-46.

[3] Han Liu, Zhang Yan. An Analysis on the Management of Nongovernmental Youth Organizations[J]. Journal of Ideological and Theoretical Education. Jun, 2010. Page107-109. 